\title{
Genome wide snRNP motifs and regulatory sequences in HIV1 isolates
}

\author{
Paushali Roy*, Protip Basu, Sayak Ganguli and Abhijit Datta \\ DBT-Centre for Bioinformatics, Presidency College, Kolkata, India. \\ *corresponding author: paushali.06@gmail.com
}

\begin{abstract}
The pathogenesis of HIV-1 is complex and characterized by the interplay of both viral and host factors. Within HIV 1 genome there are several snRNP motifs responsible for pre mRNA splicing and stabilization. By locating these motifs within the genome and disturbing them may result in an impaired ability of the cells to sustain HIV-1 replication. One of such regulatory sequences is riboswitches that regulate the dimerization of HIV-1 RNA, which is an essential step during packaging. The current work was undertaken to identify possible regulatory RNA motifs in the HIV1 genome from different isolates. The current work has successfully identified multiple snRNP motifs in the genome sequences of different strains of HIV-1 isolates. The identification of the multiple snRNP motifs in the genomic sequences of the various isolates lead us to believe that future studies with artificially constructed snRNPs might have the potential to inhibit HIV1 replication. Apart from containing snRNP motifs they also possess regulatory riboswitch motifs. Riboswitches bind metabolites and control the dimerization and packaging of the genome. Thus the occurrence of such motifs further strengthens the idea that apart from serving as a regulatory domain for structural constraints such motifs may also regulate genome integration and production of the necessary products by using the host transcriptional machinery. It is however beyond doubt that such sequence motifs must have originated in the RNA world as they have the power to mediate RNA induced regulation of gene expression.
\end{abstract}

Keywords: Riboswitch, snRNP motifs, HIV-1, gene regulation, RNA processing

\section{INTRODUCTION}

The human immunodeficiency virus type 1 (HIV-1) is the primary cause of the acquired immunodeficiency syndrome (AIDS), which is a slow, progressive and degenerative disease of the human immune system. The pathogenesis of HIV-1 is complex and characterized by the interplay of both viral and host factors. Despite years of intensive research and some therapeutic success, AIDS, continues to be a major health problem worldwide. It is a type of lentivirus and widely recognized as the etiologic agent of acquired immunodeficiency syndrome (aids). It is characterized by its cytopathic effect and affinity for the t4-lymphocyte. The strains of HIV-1 can be classified into three groups: the "major" group M, the "outlier" group $\mathrm{O}$ and the "new" group N. These three groups may represent three separate introductions of simian immunodeficiency virus into humans [1]. The enzyme reverse transcriptase (RT) is used by HIV 1 (a retrovirus) to transcribe their singlestranded RNA genome into single-stranded DNA and to subsequently construct a complementary strand of DNA, providing a DNA double helix capable of integration into host cell chromosomes. Functional HIV1-RT is a heterodimer containing subunits of $66 \mathrm{kDa}$ (p66) and $51 \mathrm{kDa}$ (p51) [2]. Many viral or cellular genes are involved in HIV-1 multiplication and therefore represent potential targets. Indeed, several strategies attempting to interfere with the production or function of such gene products are being tested at preclinical or clinical levels. Within HIV 1 genome there are several snRNPs (small nuclear ribonucleoproteins) motifs mainly responsible for pre mRNA splicing and stabilization. By locating these motifs within the genome and disturbing them may result in an impaired ability of the cells to sustain HIV-1 replication. HIV-1 pathogenesis is multifactorial and involves complex interactions between host and viral genes [3]. Several regulatory sequences that play significant role in HIV-1 infection have been so far identified. One of such regulatory sequences is riboswitches that regulate the dimerization of HIV-1 RNA, which is an essential step during packaging. Riboswitches are complex folded RNA domains that serve as receptors for specific metabolites. These domains are found in the non-coding portions of various mRNAs, where they control gene expression by harnessing allosteric structural changes that are brought about by metabolite binding. New findings indicate that riboswitches are robust genetic elements that are involved in regulating fundamental metabolic processes in many organisms. The riboswitches are made up of the threedimensional structure of RNA, in which RNA can undergo two mutually exclusive conformations in response to an environmental signal in the form of a metabolite. Riboswitches comprise two domains: an aptamer and an expression platform. The aptamer is highly conserved even in distantly related organisms, and serves as a precise sensor for its target metabolite. The expression platform is far more variable in sequence and in structure as it can function by assuming one of many structural forms to control gene expression [4]. For all these reasons riboswitches seem to be a significant form of genetic control. The advantage of this system is that they are highly specific to their substrates. But the lack of universality is because riboswitch-mediated translational regulation is limited to monocistronic m-RNA. Riboswitches have been shown to function in repressing gene expression (negative regulation) in response to metabolites. If riboswitch is a primitive mode of gene regulation4 then it suggests that in the RNA world negative regulation was predominant. There are also speculations that riboswitch-mediated control mechanism might 
also be playing an important role in eukaryotic gene expression. Unlike prokaryotes, eukaryotes have distinct compartments for transcription and translation and m-RNA is monocistronic. These favour posttranscriptional and translational gene regulation. A riboswitch-mediated gene regulation is expected to be acting either at post-transcriptional or translational level [5]. Each riboswitch is able to bind with high specificity their cellular target metabolite, without the involvement of a protein cofactor. Upon metabolite binding, the messenger RNA undergoes structural change that will ultimately lead to the modulation of its genetic expression. Riboswitches can alter gene expression at the level of transcription attenuation or translation initiation, and can upor down-regulate gene expression by harnessing appropriate changes in the mRNA structure.

The following riboswitches are known:

- TPP riboswitch (also THI-box) binds thiamin pyrophosphate (TPP) to regulate thiamin biosynthesis and transport, as well as transport of similar metabolites [6].

- FMN riboswitch (also RFN-element) binds flavin mononucleotide (FMN) to regulate riboflavin biosynthesis and transport [7].

- Cobalamin riboswitch (also B12element), which binds adenosylcobalamin (the coenzyme form of vitamin B12) to regulate cobalamin biosynthesis and transport of cobalamin and similar metabolites, and other genes [8].

- $\quad$ SAM riboswitches bind S-adenosyl methionine (SAM) to regulate methionine and SAM biosynthesis and transport. Three distinct SAM riboswitches are known: SAM-I (originally called $S$-box), SAM-II and the SAM (MK) riboswitch. SAM-I is widespread in bacteria, but SAM-II is found only in alpha-, beta- and a few gamma-proteobacteria. SAM (MK) is found only in the order Lactobacillales. These three varieties of riboswitch have no obvious similarities in terms of sequence or structure [9].

- Purine riboswitches binds purines to regulate purine metabolism and transport. Different forms of the purine riboswitch can bind either guanine (a form originally known as the G-box) or adenine. The specificity for either guanine or adenine depends completely upon Watson-Crick interactions with a single pyrimidine in the riboswitch at position Y74. In the guanine riboswitch this residue is always a cytosine (i.e. C74), in the adenine residue it is always a uracil (i.e. U74) [10]

- Lysine riboswitch (also L-box) binds lysine to regulate lysine biosynthesis, catabolism and transport [10].

- $\quad g l m S$ riboswitch, which is a ribozyme that cleaves itself when there is a sufficient concentration glucosamine-6-phosphate [11].

- Glycine riboswitch binds glycine to regulate glycine metabolism genes, including the use of glycine as an energy source. As of 2007, this riboswitch is the only known natural RNA that exhibits cooperative binding, which is accomplished by two adjacent aptamer domains in the same mRNA [12].

- Magnesium riboswitch senses magnesium ions to regulate magnesium transport genes [13].

- PreQ1 riboswitch binds prequeuosine $_{1}$, to regulate genes involved in the synthesis of this precursor to queuosine. The binding domain of this riboswitch is unusually small among naturally occurring riboswitches [14].

- Adenine riboswitch, smallest riboswitch that activates gene expression upon ligand binding [15].

- Guanine riboswitch [16].

Thus a likely scenario is such that there may be more than one regulatory RNA motif that may be present and be involved in the control of gene expression not only at the transcriptional level but also co - translationally. The current work was undertaken to identify possible regulatory RNA motifs in the HIV1 genome from different isolates.

\section{MATERIALS AND METHOD}

A total of 42 sequences of HIV1 genome were collected from the NCBI databases. RNA sequences of all the sequences of HIV1 genome were designed using a number of closely related software applications. General information of RNA sequences (including poly (A) signal, catalytic RNA, snRNP motifs, putative UTRs, promoter regions, AU-rich regions, etc.) were retrieved using software tool-box for analysis of regulatory RNA elements. Apart from this, regulatory sequences/riboswitches in the RNA sequences were determined using a RNA motif search program and web server which checks specific sequence elements and secondary structure, calculates and displays the energy folding of the RNA structure and runs a number of tests including this information to determine whether high-sensitivity riboswitch motifs (or variants) are present in the given RNA sequence. Batchmode determination (all sequences input at once and separated by FASTA format) is also possible. Structures of riboswitches were 
analyzed. Riboswitch sequences were obtained from the RNA sequences.

\section{RESULTS}

snRNP motifs: Among 42 sequences studied, snRNP motifs were identified in only 34 sequences.

Total snRNP motifs-1194 in 34 sequences.

Riboswitch regulatory sequences: Among 42 sequences studied, riboswitches are found in 30 sequences [Table-I].

\section{DISCUSSION:}

Maturation of pre-mRNA in eukaryotes involves a set of factors that modify the primary transcript into an export competent mRNP (messenger ribonucleoprotein) complex, the formation of which, signals its release from the site of transcription and export into the cytoplasm for translation. These processing events include capping, splicing, 3' end cleavage and polyadenylation. Proper 3' end formation promotes transcription termination and nuclear export of the mRNA and enhances the stability and translation of the mature transcript in the cytoplasm. Recent evidence implicates the existence of extensive coupling between the gene expression machinery engaged in mRNA synthesis, processing, export and surveillance suggesting that disruption of RNA processing will compromise proper gene expression [17]. The current work has successfully identified multiple snRNP motifs in the genome sequences of different strains of HIV-1 isolates. It is known that binding of modified snRNP inhibits the polyadenylation step in 3' end formation by disrupting the protein-protein interactions in the polyadenylation machinery [18]. In contrast, interaction between snRNP and the major splice donor site downstream of the HIV-1 5' LTR poly $(A)$ site inactivates the cleavage step in a U1 $70 \mathrm{~K}$ dependent manner and is thought to be important for production of full-length genomic RNA [19]. Thus the identification of the multiple snRNP motifs in the genomic sequences of the various isolates lead us to believe that future studies with artificially constructed snRNPs might have the potential to inhibit HIV1 replication. Further more the snRNP motifs if found homologous with any other such motifs in the human spliceosomal machinery may also provide insight on some other possible mode of prevention of HIV1 infection. Most of the sequences under study have revealed that apart from containing multiple snRNP motifs they also possess regulatory riboswitch motifs. Riboswitches, as we know bind metabolites and control the dimerization and packaging of the genome. Thus the occurrence of such motifs further strengthens the idea that apart from serving as a regulatory domain for structural constraints such motifs may also regulate genome integration and further production of the necessary products by using the host transcriptional machinery. It is however beyond 16 doubt that such sequence motifs must have originated in the RNA world as they have the power to mediate RNA induced regulation of gene expression.

\section{Riboswitch Topology:}

Most of the riboswitches that were obtained consist of simple stem loops and bulges. Very few are there showing branches. The details of each riboswitches are as follows:

$>\quad>$ gi|9629914|ref|NC_001870.1|Simi an-Human immunodeficiency virus, complete genome: There are 6 bulges (one is incomplete) and 1 stem loop structure [Fig. (1)].

$>\quad>$ gi|156067835|gb|EU030417.2|HIV -1 isolate cd07_005 pol protein (pol) gene, partial cds: There are 4 bulges (one is incomplete) and 1 stem loop structure [Fig. (2)]

$>\quad>$ gi|151368121|gb|EF545108.1|HIV -1 isolate RU00051, complete genome: There are 4 bulges (one is incomplete) and 1 stem loop structure [Fig. (3)].

> >gi|149939408|gb|EF633445.1|HIV -1 isolate R1, complete genome: There are 3 bulges and 1 stem loop structure. The third bulge consists of 2 branches; $1^{\text {st }}$ branch consists of 1 bulge and 1 stem loop and the $2^{\text {nd }}$ branch consist of 2 bulges (one is incomplete) and 1 stem loop structure [Fig. (4)].

$>\quad>$ gi|149211372|gb|EF078279.2|HIV -1 isolate TW-D118, partial genome: There are 5 bulges (one is incomplete) and one stem loop structure [Fig. (5)].

$>\quad>$ gi|149211364|gb|EF078278.2|HIV -1 isolate TW-D4, partial genome: There are 5 bulges (one is incomplete) and one stem loop structure [Fig. (6)].

$>\quad>$ gi|117581798|gb|EF036534.1|HIV -1 isolate Fj065 complete genome: there are 6 bulges of which two motifs are concurrent ones. All bulges are attached by stem helices. [Fig (7)].

$>\quad>$ gi|117643940|gb|EF029066.1|HIV -1 isolate U.NL.95.H10986_D1, complete genome: There are 5 bulges and one stem loop structure [Fig. (8)].

$>\quad>$ gi|62532627|gb|AY857174.2|HIV1 isolate 9340158 partial genome: There are 5 bulges (one is incomplete) and one stem loop structure [Fig. (9)].

$>\quad>$ gi|113171669|gb|DQ854716.1|HIV -1 isolate U61 complete genome: There are 7 bulges (one is incomplete) and one stem loop structure [Fig. (10)].

$>\quad>$ gi|94959078|gb|DQ487188.1|HIV1 isolate WCD32P0793, complete 
genome: There are 7 bulges (one is incomplete) and one stem loop structure [Fig. (11)].

$>\quad>$ gi|121581791|dbj|AB289588.1|Hu man immunodeficiency virus 1 proviral DNA, complete genome, clone: p00JPDR2508B60: There are 7 bulges (one is incomplete) and one stem loop structure [Fig. (12)].

$>\quad>$ gi|116518650|gb|DQ886035.1|HIV -1 isolate L8157, complete genome: 5 bulges of which two are concurrent on the main stem. The main stem culminates in an incomplete bulge loop [Fig. (13)].

$>\quad>$ gi|51980229|gb|AY612637.1|HIV1 isolate PT2695, complete genome: There are 7 bulges (one is incomplete) and one stem loop structure [Fig. (14)].

$>\quad>$ gi|119370128|gb|EF091932.1|HIV -1 isolate 110PA, complete genome: There are 7 bulges (one is incomplete) and one stem loop structure [Fig. (15)].

$>\quad>$ gi|119507379|dbj|AB287367.1|Hu man immunodeficiency virus 1 proviral DNA, complete genome, clone: p05JPDR7060B68: There are 6 bulges (one is incomplete) and one stem loop structure [Fig. (16)].

$>\quad>$ gi|112497920|gb|DQ676884.1|HIV -1 isolate PS3002_Day199, complete genome: There are 6 bulges (one is incomplete) and one stem loop structure [Fig. (17)].

$>\quad>$ gi|86277646|gb|DQ358812.1|HIV1 isolate 02BR034, complete genome: There are 5 bulges (one is incomplete) and one stem loop structure [Fig. (18)].

$>\quad>$ gi|63098379|gb|DQ011175.1|HIV1 isolate 03ZASK005B2, complete genome: There are 4 bulges and one stem loop structure [Fig. (19)]

$>\quad>g i|50404184| \mathrm{gb} \mid$ AY682547.1|HIV1 isolate 04RU128005, complete genome: 4 bulge loops terminated by incomplete bulge [Fig. (20)].

$>\quad>$ gi|29409314|gb|AY093605.1|HIV1 isolate 96GH2911, complete genome: There are 6 bulges (one is incomplete) and one stem loop structure [Fig. (21)].

$>\quad>$ gi|18643009|gb|AY074891.1|HIV1 isolate 00BWMO35.1, complete genome: 4 bulges with 3 stems and one concurrent bulge motif. [Fig. (22)]

$>\quad>$ gi|17902136|gb|AF423759.1|HIV1 isolate $\mathrm{X} 477$, complete genome: There are 7 bulges (one is incomplete) and one stem loop structure [Fig. (23)].
>gi|15788267|gb|AF408629.1|HIV1 isolate A32879, complete genome: There are 5 bulges (one is incomplete) and one stem loop structure [Fig. (24)].

$>\quad>$ gi|7321133|emb|AJ276595.1|HIV1 proviral gag gene, pol gene, vif gene, vpr gene, vpu gene, env gene, nef gene, tat gene and rev gene, isolate VI1035, genomic RNA: There are 5 bulges (one is incomplete) and two stem loop structures [Fig. (25)]

$>\quad>$ gi|47680175|gb|AY530889.1|HIV2 isolate 96FR12034, complete genome: There are 5 bulges (one is incomplete) and one stem loop structure [Fig. (26)].

$>\quad>$ gi|114801456|gb|DQ853465.1|HIV -1 isolate 14301.1 complete genome: There are 6 bulges (one is incomplete) and one stem loop structure [Fig. (27)].

$>\quad>$ gi|114801377|gb|DQ853457.1|HIV -1 isolate 15389.1, complete genome: There are 6 bulges (one is incomplete) and one stem loop structure [Fig. (28)].

$>\quad>$ gi|114801193|gb|DQ853438.1|HIV -1 isolate 14300.1 , complete genome: There are 7 bulges (one is incomplete) and one stem loop structure [Fig. (29)].

$>\quad>$ gi|108860394|dbj|AB231893.1|Hu man immunodeficiency virus 1 proviral DNA, complete genome, isolate: GHNJ175: There are 2 bulges and 1 stem loop structure. The second bulge consists of two branches; $1^{\text {st }}$ branch consists of 1 bulge and 1 stem loop structure and the second branch consists of three concurrent bulges [Fig. (30)].

\section{REFERENCES}

[1] Nishitsuji H. , Kohara M. , Kannagi M. and Masuda T. (2006) J Virol, 80, 76587666.

[2] Jacobo-Molina A. , Ding J., , Nanni R.G. , Clark A.D. , Jr., Lu X. , Tantillo C. Williams R.L. , Kamer G. , Ferris A.L. Clark P. , Hizi A, Hughes S.H. and Arnold E. (1993) Proc. Natl. Acad. Sci. USA 90, 6320-6324.

[3] Chakraborti S. and Banerjea A.C. (2003) Mol Ther 7, 817-826.

[4] Mandal M. and Breaker R. R. (2004) Nature Reviews Molecular Cell Biology 5, 451-463.

[5] Ray S. Kumar (2004) Current Science 87(9).

[6] Miranda-Ríos J. , Navarro M. and Soberón M. (2001) Proc Natl Acad Sci U S A 98(17), 9736-41. 
[7] Winkler W.C. , Cohen-Chalamish S. and Breaker R.R. (2002) Proc Natl Acad Sci U S A 99(25), 15908-13.

[8] Nahvi A. , Barrick J.E. and Breaker R.R. (2004) Nucleic Acids Res. 32(1), 14350.

[9] Grundy F.J. and Henkin T.M. (1998) Mol Microbiol 30(4), 737-49.

[10] Mandal M. (2003) Cell 113, 577-586.

[11] Winkler W.C. , Nahvi A., Roth A. , Collins J.A. and Breaker R.R. (2004) Nature 428, 281-286.

[12] Mandal M. , Lee M. , Barrick J.E. , Weinberg Z. , Emilsson G.M. , Ruzzo W.L. and Breaker R.R. (2004) Science 306, 275-279.
[13] Tucker B.J. and Breaker R.R. (2005) Curr Opin Struct Biol 15(3), 342-8.

[14] Roth A. (2007) Nat Struct Mol Biol 14(4), 308-17.

[15] Kaempfer R. (2003) EMBO reports 4(11), 1043-1047.

[16] Batey R.T. , Gilbert S.D. and Montange R.K. (2004) Nature 432, 411-415.

[17] Sajic R. , Lee K. , Asai K. , Sakac D. , Branch D.R. , Upton C. and Cochrane A. (2007) Nucleic Acids Research, 35, 247-255.

[18] Vagner S. , Rüegsegger U. , Gunderson S.I. , Keller W. and Mattaj I.W. (2000) $R N A, 6,178-188$.

[19] Ashe M.P. , Furger A. and Proudfoot N.J. (2000) RNA, 6, 170-177. 
TABLE I: Identified snRNP motifs and riboswitches in HIV-1 genome

\begin{tabular}{|c|c|c|c|c|c|c|c|c|}
\hline $\begin{array}{c}\text { S.N } \\
\text { o. }\end{array}$ & Accession No. & Name & Country & \multicolumn{3}{|c|}{ snRNP } & Riboswitch & $\begin{array}{l}\text { Riboswitch } \\
\text { Position }\end{array}$ \\
\hline 1. & $\begin{array}{l}\text { gi|2828036|gb| } \\
\text { AF038398.1|AF0 } \\
38398\end{array}$ & $\begin{array}{l}\text { Simian-Human } \\
\text { immunodeficiency virus } \\
\text { strain SHIV-89.6, } \\
\text { complete genome }\end{array}$ & NA & $\begin{array}{l}\text { Start s } \\
581 \\
1190 \\
2198 \\
2836 \\
3348 \\
3916 \\
4663 \\
4920 \\
818 \\
17189 \\
7668\end{array}$ & $\begin{array}{c}706 \\
1492 \\
2282 \\
2997 \\
3490 \\
4315 \\
4805 \\
5099 \\
5872 \\
7381 \\
8710\end{array}$ & $\begin{array}{r}749 \\
1943 \\
2389 \\
3161 \\
3583 \\
4647 \\
4814 \\
5727 \\
6000 \\
7446 \\
9257\end{array}$ & Not found & \\
\hline 2. & $\begin{array}{l}>\text { gi|9629914|ref| } \\
\text { NC_001870.1| }\end{array}$ & $\begin{array}{l}\text { Simian-Human } \\
\text { immunodeficiency virus, } \\
\text { complete genome }\end{array}$ & NA & $\begin{array}{l}\text { Start s } \\
581 \\
1190 \\
2198 \\
2836 \\
348 \\
3916 \\
4663 \\
4920 \\
5818 \\
7189 \\
7668 \\
10299 \\
10781 \\
11540 \\
12393 \\
13059 \\
14079 \\
14321 \\
15320 \\
16246 \\
16875 \\
18148\end{array}$ & $\begin{array}{c} \\
706 \\
1492 \\
2282 \\
2997 \\
3490 \\
4315 \\
4805 \\
5099 \\
5872 \\
7381 \\
8710 \\
10525 \\
10885 \\
12237 \\
12996 \\
13132 \\
14201 \\
14404 \\
15429 \\
16298 \\
17109 \\
18568\end{array}$ & $\begin{array}{r}749 \\
1943 \\
2389 \\
161 \\
3583 \\
4647 \\
4814 \\
727 \\
6000 \\
7446 \\
9257 \\
10722 \\
11235 \\
12347 \\
13023 \\
13345 \\
14247 \\
14425 \\
16183 \\
16612 \\
17674 \\
18950\end{array}$ & 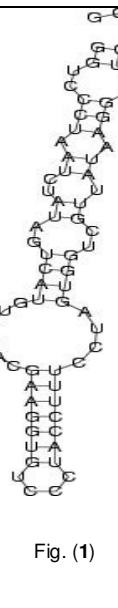 & $\begin{array}{l}\text { + strand, position } \\
12513 \\
\text { And } \\
\text { + strand, position } \\
12606\end{array}$ \\
\hline 3. & $\begin{array}{l}>g i|156067837| g \\
\text { b|EU030418.2 }\end{array}$ & $\begin{array}{l}\text { HIV-1 isolate vl05_153 } \\
\text { pol protein (pol) gene, } \\
\text { partial cds }\end{array}$ & India & & NONE & & Not found & \\
\hline 4. & $\begin{array}{l}>\text { gi|156067835|g } \\
\text { b|EU030417.2| }\end{array}$ & $\begin{array}{l}\text { HIV-1 isolate cd07_005 } \\
\text { pol protein (pol) gene, } \\
\text { partial cds }\end{array}$ & India & $\begin{array}{l}\text { Start s } \\
184 \\
550\end{array}$ & $\begin{array}{l}438 \\
596\end{array}$ & 473 & 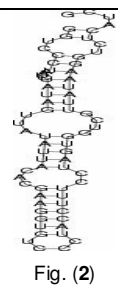 & $\begin{array}{c}\text { + strand, position } \\
716\end{array}$ \\
\hline 5. & $\begin{array}{l}>\text { gi|155964970|g } \\
\text { b|EU008325.1| }\end{array}$ & $\begin{array}{l}\text { HIV-1 isolate patient D } \\
\text { clone } M \text { envelope } \\
\text { glycoprotein (env) gene, } \\
\text { partial cds }\end{array}$ & Belgium & & NONE & & Not found & \\
\hline 6. & $\begin{array}{l}>\text { gi|155964942| } \\
\text { gb|EU008311.1| }\end{array}$ & $\begin{array}{l}\text { HIV-1 isolate patient D } \\
\text { clone L envelope } \\
\text { glycoprotein (env) gene, } \\
\text { partial cds }\end{array}$ & Belgium & & NONE & & Not found & \\
\hline 7. & $\begin{array}{l}>\text { gi|9628880|ref| } \\
\text { NC_001722.1| }\end{array}$ & $\begin{array}{l}\text { Human } \\
\text { immunodeficiency virus } \\
\text { 2, complete genome }\end{array}$ & NA & $\begin{array}{l}\text { Start s } \\
275 \\
1316 \\
1862 \\
3436 \\
3664 \\
4204 \\
5037\end{array}$ & $\begin{array}{c} \\
693 \\
1338 \\
1973 \\
3547 \\
3761 \\
4409 \\
5083\end{array}$ & $\begin{array}{l}1273 \\
1757 \\
3186 \\
3597 \\
4090 \\
4915 \\
5250 \\
\end{array}$ & Not found & \\
\hline
\end{tabular}




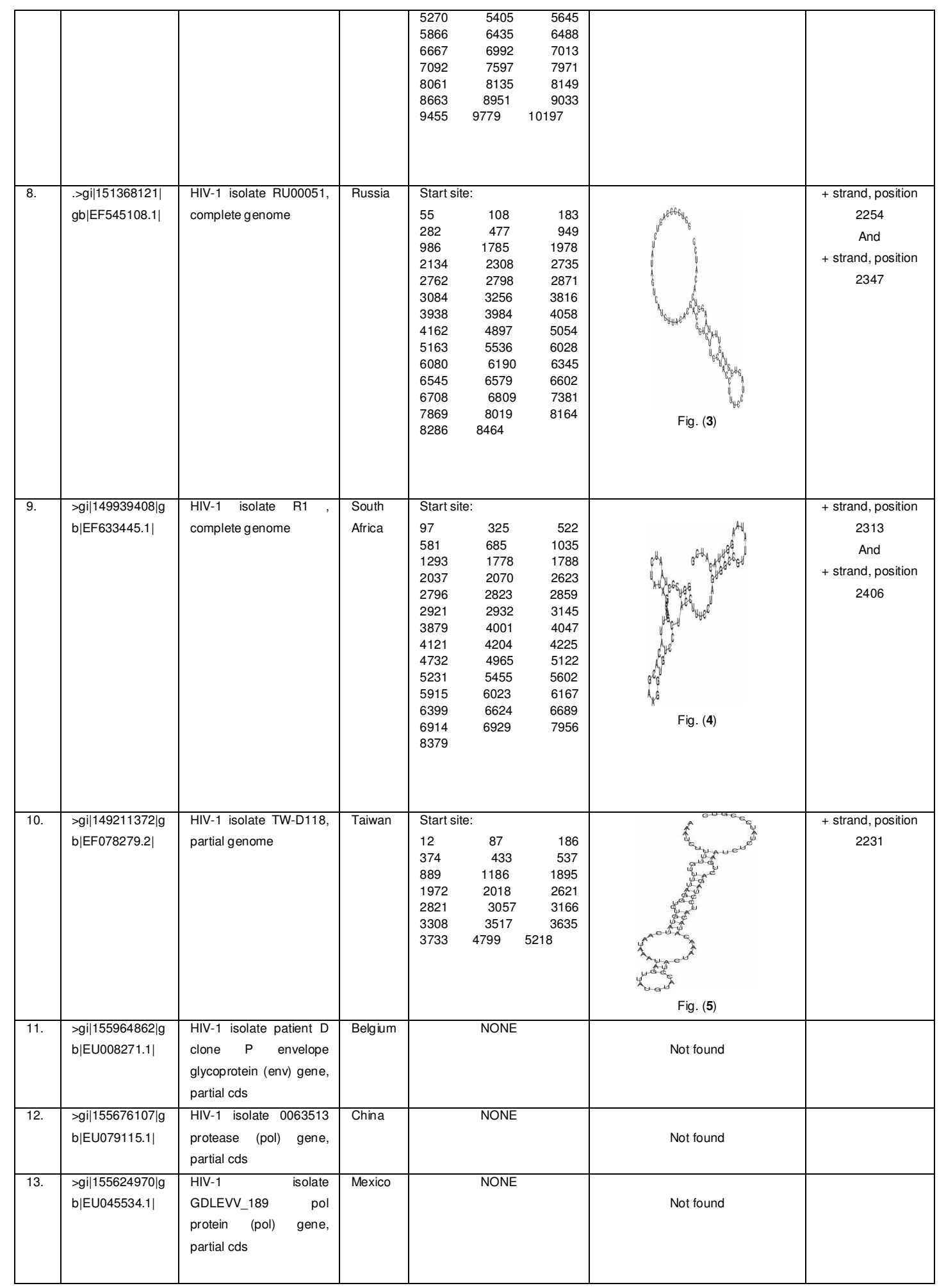




\begin{tabular}{|c|c|c|c|c|c|c|c|c|}
\hline 14. & $\begin{array}{l}>\text { gi||149211364|g } \\
b|E F 078278.2|\end{array}$ & $\begin{array}{l}\text { HIV-1 isolate TW-D4, } \\
\text { partial genome }\end{array}$ & Taiwan & \begin{tabular}{l|} 
Start \\
12 \\
374 \\
889 \\
1895 \\
2621 \\
2757 \\
3411 \\
4417 \\
5848 \\
7130 \\
\end{tabular} & $\begin{array}{c}87 \\
433 \\
1138 \\
1972 \\
2684 \\
2970 \\
4072 \\
4556 \\
5966 \\
7550\end{array}$ & $\begin{array}{r}186 \\
537 \\
1186 \\
2018 \\
2746 \\
3307 \\
4308 \\
5326 \\
6064\end{array}$ & Fig. (6) & $\begin{array}{c}\text { + strand, position } \\
2231\end{array}$ \\
\hline 15. & $\begin{array}{l}>\text { gi|30793424|db } \\
\text { j|AB085203.1| }\end{array}$ & $\begin{array}{l}\text { Human } \\
\text { immunodeficiency virus } \\
1 \text { genes for pol protein } \\
\text { (p6pol region) and gag } \\
\text { protein (p6gag region), } \\
\text { partial cds, isolate: } \\
\text { patient \#18 }\end{array}$ & NA & & NONE & & Not found & \\
\hline 16. & $\begin{array}{l}>\mathrm{gi}|117581798| \mathrm{g} \\
\mathrm{b}|\mathrm{EF} 036534.1|\end{array}$ & $\begin{array}{l}\text { HIV-1 isolate Fj065 } \\
\text { complete genome }\end{array}$ & China & $\begin{array}{l}\text { Start } \\
319 \\
1191 \\
1704 \\
2700 \\
3486 \\
3808 \\
4664 \\
4867 \\
5187 \\
5891 \\
6819 \\
7536 \\
8578 \\
9382\end{array}$ & $\begin{array}{l} \\
820 \\
1405 \\
1804 \\
2856 \\
3522 \\
3980 \\
4710 \\
\\
5625 \\
6033 \\
7084 \\
7967 \\
8873\end{array}$ & $\begin{array}{r}888 \\
1669 \\
2003 \\
3459 \\
3595 \\
4542 \\
4784 \\
4888 \\
5782 \\
6162 \\
7344 \\
8181 \\
9000\end{array}$ & Fig. (7) & $\begin{array}{c}\text { + strand, position } \\
2976, \\
\text { + strand, position } \\
3069 \\
\text { And } \\
\text { - strand, position } \\
7554\end{array}$ \\
\hline 17. & $\begin{array}{l}>\text { gi|117643940|g } \\
b|E F 029066.1|\end{array}$ & $\begin{array}{l}\text { HIV-1 isolate } \\
\text { U.NL.95.H10986_D1, } \\
\text { complete genome }\end{array}$ & $\begin{array}{l}\text { Netherl } \\
\text { ands }\end{array}$ & $\begin{array}{l}\text { Start } \\
777 \\
1123 \\
1579 \\
2686 \\
3335 \\
3684 \\
4586 \\
4999 \\
6219 \\
6936 \\
7463 \\
8508 \\
9132\end{array}$ & $\begin{array}{c} \\
876 \\
1227 \\
1879 \\
2732 \\
3362 \\
4418 \\
4660 \\
5658 \\
6566 \\
6963 \\
8075 \\
8574\end{array}$ & $\begin{array}{l}1064 \\
1542 \\
2576 \\
2936 \\
3398 \\
4540 \\
4764 \\
5909 \\
6698 \\
7226 \\
8148 \\
8949\end{array}$ & 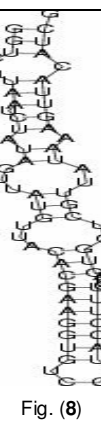 & $\begin{array}{c}\text { + strand, position } \\
2852 \\
\text { And } \\
\text { + strand, position } \\
2945\end{array}$ \\
\hline 18. & $\begin{array}{l}>\text { gi|62532627|gb } \\
\mid \text { AY857174.2| }\end{array}$ & $\begin{array}{l}\text { HIV-1 isolate } 9340158 \\
\text { partial genome }\end{array}$ & $\begin{array}{l}\text { Australi } \\
\text { a }\end{array}$ & \begin{tabular}{l|} 
Start \\
132 \\
655 \\
1000 \\
2080 \\
3358 \\
3573 \\
5024 \\
\end{tabular} & $\begin{array}{r}492 \\
706 \\
1714 \\
2126 \\
3404 \\
4399\end{array}$ & $\begin{array}{r}551 \\
964 \\
1968 \\
2300 \\
3476 \\
4504\end{array}$ & 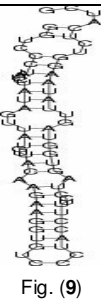 & $\begin{array}{c}\text { + strand, position } \\
2246\end{array}$ \\
\hline 19. & $\begin{array}{l}>\mathrm{gi}|113171669| \mathrm{g} \\
\mathrm{b}|\mathrm{DQ} 854716.1|\end{array}$ & $\begin{array}{l}\text { HIV-1 isolate U61 } \\
\text { complete genome }\end{array}$ & Spain & $\begin{array}{l}\text { Start } \\
756 \\
1178 \\
1996 \\
2803 \\
3479 \\
3801 \\
4657 \\
4860 \\
5621 \\
6638 \\
7351\end{array}$ & $\begin{array}{c}882 \\
1237 \\
2434 \\
2849 \\
3515 \\
3954 \\
4703 \\
4881 \\
5778 \\
6722 \\
7579\end{array}$ & $\begin{array}{r}981 \\
1341 \\
2693 \\
3452 \\
3588 \\
4535 \\
4777 \\
5388 \\
5887 \\
7286 \\
7628\end{array}$ & 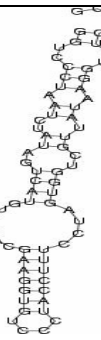 & $\begin{array}{c}\text { + strand, position } \\
2969 \\
\\
\text { And } \\
+ \text { strand, position } \\
3062\end{array}$ \\
\hline
\end{tabular}




\begin{tabular}{|c|c|c|c|c|c|c|c|c|}
\hline & & & & 8624 & 9044 & & Fig. (10) & \\
\hline 20. & $\begin{array}{l}>\mathrm{gi}|94959078| \mathrm{gb} \\
\mid \mathrm{DQ487188.1|}\end{array}$ & $\begin{array}{l}\text { HIV-1 isolate } \\
\text { WCD32P0793, complete } \\
\text { genome }\end{array}$ & USA & $\begin{array}{l}\text { Start s } \\
297 \\
882 \\
2249 \\
3008 \\
3144 \\
4213 \\
4416 \\
5098 \\
5443 \\
6386 \\
6924 \\
8227\end{array}$ & $\begin{array}{c} \\
720 \\
1232 \\
2359 \\
3035 \\
3357 \\
4259 \\
4437 \\
5236 \\
6333 \\
6859 \\
7161 \\
8646\end{array}$ & $\begin{array}{r}779 \\
1537 \\
2405 \\
3071 \\
4091 \\
4333 \\
4944 \\
5334 \\
6365 \\
6901 \\
7176\end{array}$ & & $\begin{array}{c}\text { + strand, position } \\
2525 \\
\text { And } \\
\text { + strand, position } \\
2618\end{array}$ \\
\hline 21. & $\begin{array}{l}>g i|125661184| g \\
b|E F 363123.1|\end{array}$ & $\begin{array}{l}\text { HIV-1 clone ES1-20, } \\
\text { complete genome }\end{array}$ & USA & $\begin{array}{l}\text { Start s } \\
753 \\
1235 \\
1758 \\
1994 \\
2847 \\
3513 \\
4533 \\
4775 \\
4879 \\
6651 \\
7272 \\
8148\end{array}$ & $\begin{array}{c} \\
979 \\
1339 \\
1906 \\
2691 \\
3450 \\
3586 \\
4655 \\
\\
5543 \\
6763 \\
7339 \\
8832\end{array}$ & $\begin{array}{c}1176 \\
1689 \\
1937 \\
2801 \\
3477 \\
3799 \\
4701 \\
\\
5888 \\
6854 \\
7583 \\
9042\end{array}$ & Not found & \\
\hline 22. & $\begin{array}{l}>\text { gi||121581791|d } \\
\text { bj|AB289588.1| }\end{array}$ & $\begin{array}{l}\text { Human } \\
\text { immunodeficiency virus } \\
1 \quad \text { proviral DNA, } \\
\text { complete genome, } \\
\text { clone: } \\
\text { p00JPDR2508B60 }\end{array}$ & NA & $\begin{array}{l}\text { Start s } \\
976 \\
1342 \\
1997 \\
2742 \\
3468 \\
3604 \\
4673 \\
4876 \\
5555 \\
5900 \\
7257 \\
7440 \\
8667\end{array}$ & $\begin{array}{c} \\
1179 \\
1692 \\
2161 \\
2819 \\
3495 \\
3817 \\
4719 \\
4899 \\
5693 \\
6345 \\
7376 \\
7556 \\
9036\end{array}$ & $\begin{array}{l}1238 \\
1947 \\
2709 \\
3221 \\
3531 \\
4551 \\
4793 \\
5404 \\
5791 \\
6748 \\
7410 \\
8128\end{array}$ & Fig. (12) & $\begin{array}{c}\text { + strand, position } \\
2985 \\
\text { And } \\
\text { + strand, position } \\
3078\end{array}$ \\
\hline 23. & $\begin{array}{l}>\text { gi|116518650|g } \\
\text { b|DQ886035.1| }\end{array}$ & $\begin{array}{l}\text { HIV-1 isolate L8157, } \\
\text { complete genome }\end{array}$ & USA & $\begin{array}{l}\text { Start s } \\
204 \\
564 \\
1162 \\
2038 \\
2812 \\
3770 \\
4012 \\
4657 \\
5119 \\
6515 \\
7429 \\
8474\end{array}$ & $\begin{array}{c} \\
401 \\
914 \\
1219 \\
2687 \\
2823 \\
3892 \\
4095 \\
4774 \\
5788 \\
6580 \\
7835\end{array}$ & $\begin{array}{r}460 \\
983 \\
1928 \\
2714 \\
3036 \\
3938 \\
4118 \\
5010 \\
5936 \\
6799 \\
8267\end{array}$ & 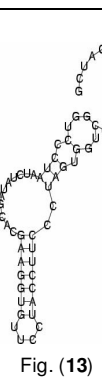 & $\begin{array}{c}\text { + strand, position } \\
2204 \\
\text { And } \\
\text { + strand, position } \\
2297\end{array}$ \\
\hline
\end{tabular}




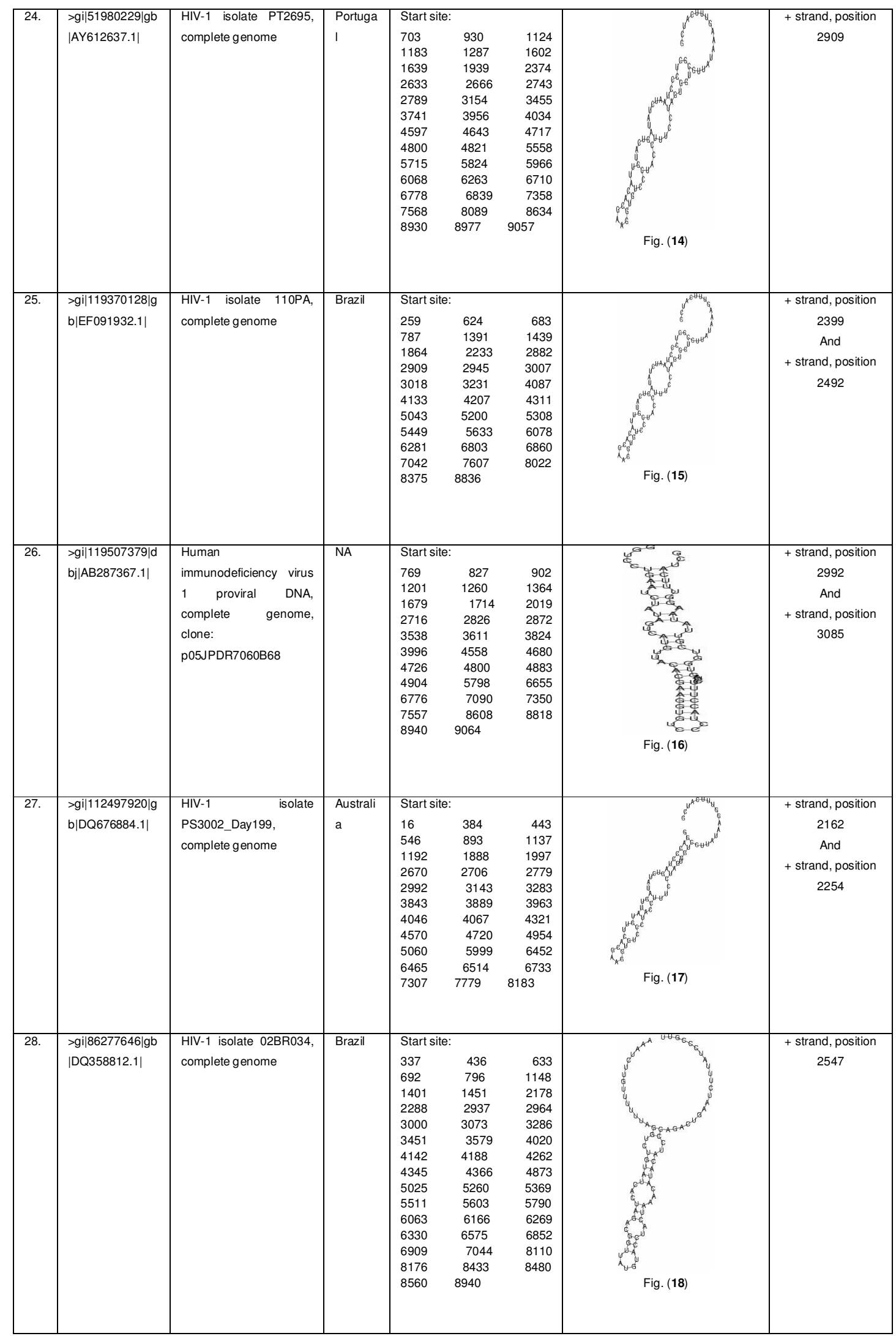




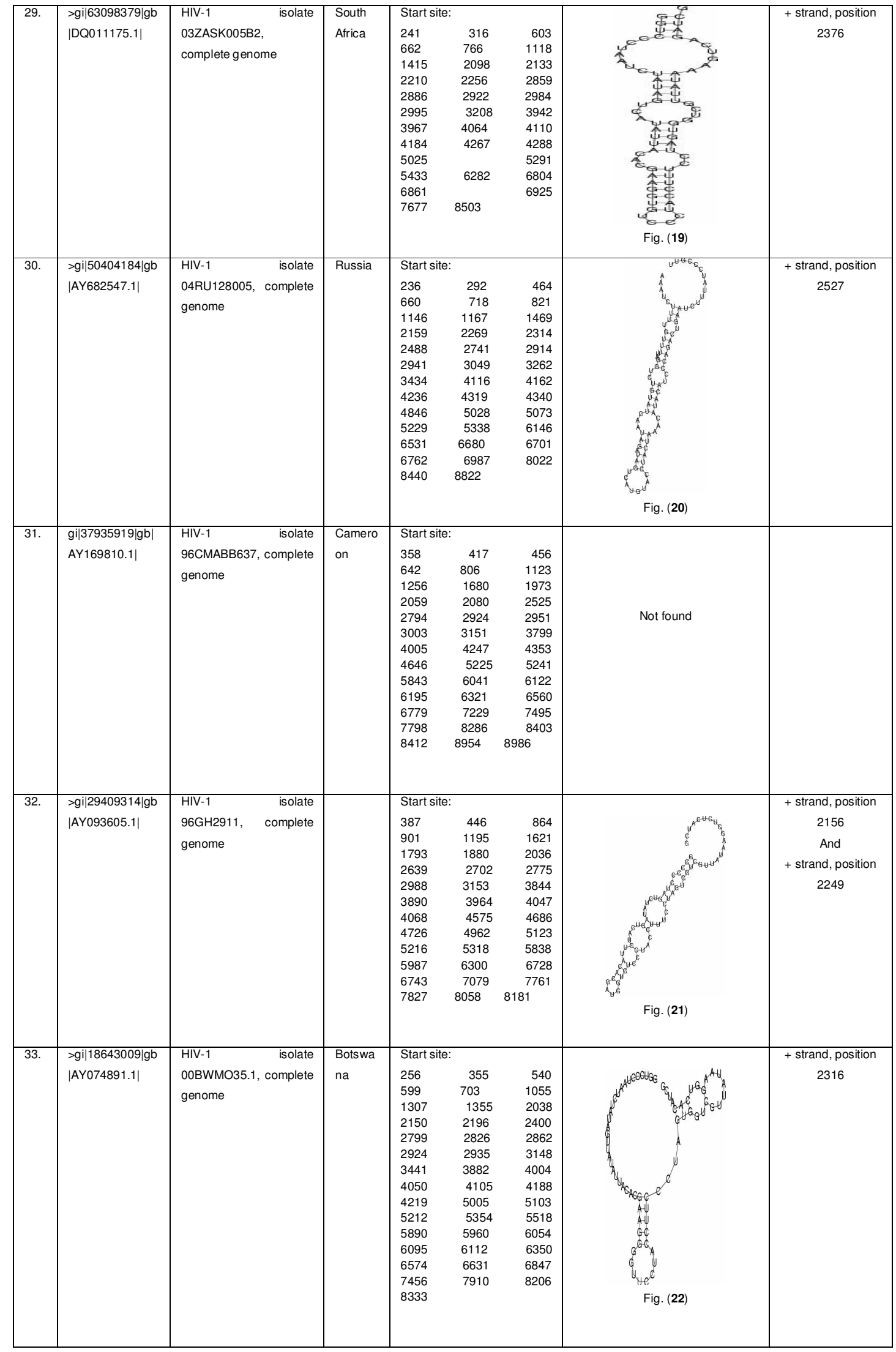




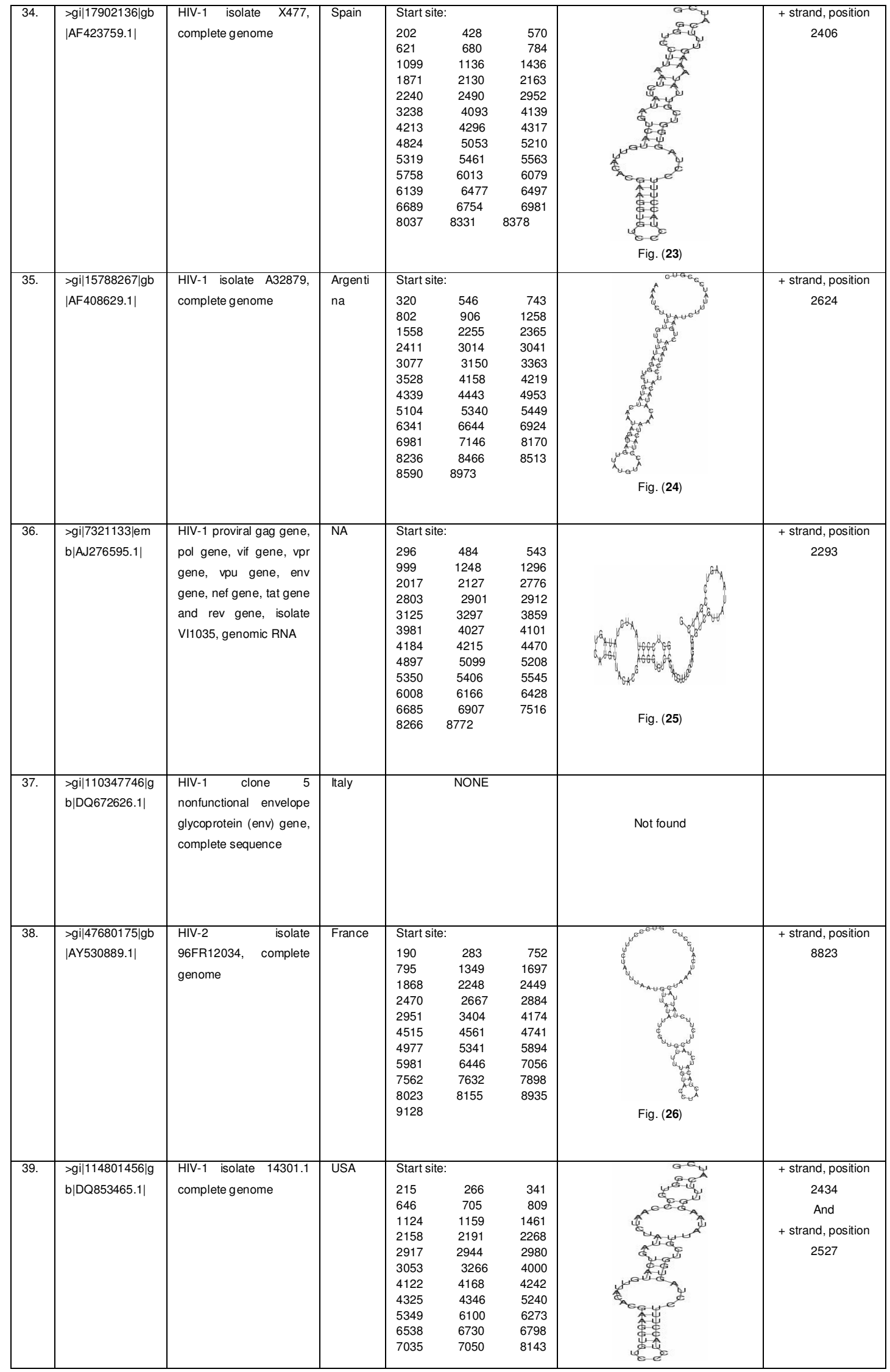




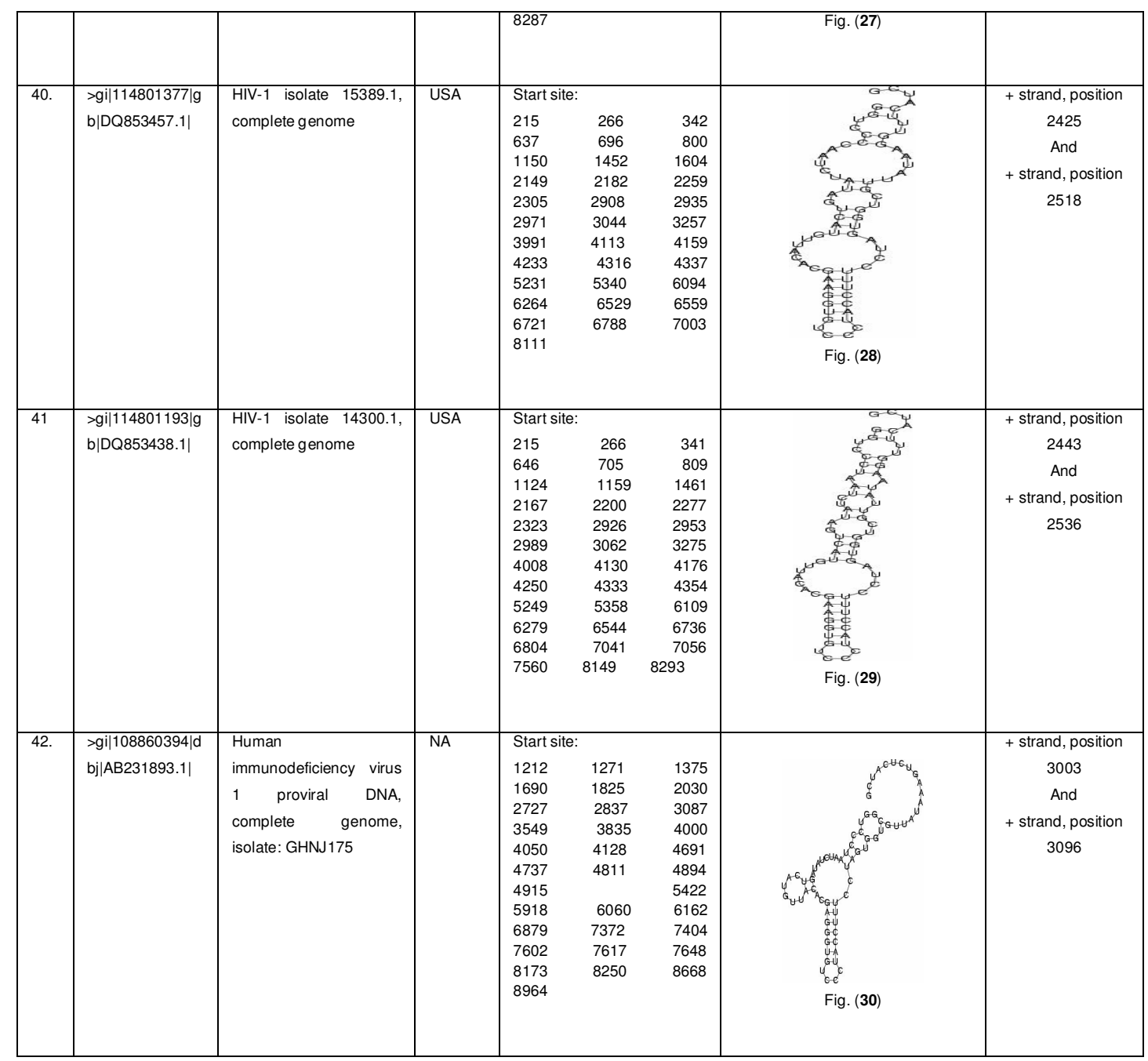

